\title{
Thyroid Cancer pN1 TNM Finding v6 and v7
}

National Cancer Institute

\section{Source}

National Cancer Institute. Thyroid Cancer pN1 TNM Finding v6 and v7. NCI Thesaurus. Code C60873.

Thyroid cancer with metastasis to regional lymph nodes. (from AJCC 6th and 7th Eds.) 